Vol 1. No 2. November 2021, e-ISSN : 2807-1808 | P-ISSN : 2807-2294

\title{
PENINGKATAN KOMPETENSI GURU MTS KECAMATAN BATEALIT KABUPATEN JEPARA DALAM MERANCANG MODEL PROJECT BASE LEARNING MELALUI WORKSHOP
}

\author{
MUSTA'IN \\ Kantor Kemenag Kab. Jepara \\ Email : mustain.mustaqimah@gmail.com
}

\begin{abstract}
ABSTRAK
Penelitian ini bertujuan untuk mendeskripsikan proses pengembangan Model Project Based Learning melalui workshop, serta meningkatkan kompetensi Guru MTs Kecamatan Batealit di Kabupaten Jepara dalam menyusun Model Project Based Learning. Penelitian dilakukan dengan dua siklus dan masing-masing siklus terdiri atas empat tahapan, yakni: perencanaan, pelaksanaan, observasi dan refleksi. Dari hasil analisis diperoleh informasi bahwa terjadi peningkatan keamampuan Guru MTs Kecamatan Batealit di Kabupaten Jepara dalam merancang Model Project Based Learning. Peningkatan itu ditunjukkan (1) kemampuan Guru MTs Kecamatan Batealit di Kabupaten Jepara dalam merancang karakteristik Model Project Based Learning dari 20\% pada siklus I menjadi 100\% pada siklus II; (2) kemampuan Guru MTs Kecamatan Batealit di Kabupaten Jepara dalam mengidentifikasi kendala Model Project Based Learning dari $27 \%$ pada siklus I menjadi $100 \%$ pada siklua II; (3) kemampuan Guru Guru MTs Kecamatan Batealit di Kabupaten Jepara dalam merancang tujuan Model Project Based Learning, dari $27 \%$ pada siklus I menjadi $100 \%$ pada siklus II; (4) kemampuan Guru MTs Kecamatan Batealit di Kabupaten Jepara dalam menyusun langkah-langkah Model Project Based Learning, dari $20 \%$ pada siklus I menjadi 100\% pada siklus II; (5) Kemampuan Guru MTs Kecamatan Batealit di Kabupaten Jepara dalam membuat rancangan Model Project Based Learning, dari $17 \%$ pada siklus I menjadi $100 \%$ pada siklus II. Informasi lain menunjukkan bahwa respon Guru MTs Kecamatan Batealit di Kabupaten Jepara dalam mengikuti proses workshop dalam rangka merancang Model Project Based Learning 67\% merespon sangat baik dan 33\% merespon baik. Ini menunjukkan bahwa Guru MTs Kecamatan Batealit di Kabupaten Jepara sangat mengharapkan adanya workshop dalam meningkatkan kompetensi mereka.
\end{abstract}

Kata kunci: kompetensi guru, PjBL, proses workshop.

\section{ABSTRACT}

This study aims to describe the process of developing a Project Based Learning Model through workshops, as well as improving the competence of MTs Teachers in Batealit District in Jepara Regency in developing Project Based Learning Models. The research was conducted in two cycles and each cycle consisted of four stages, namely: planning, implementation, observation and reflection. From the results of the analysis obtained information that there is an increase in the ability of MTs teachers in Batealit District in Jepara Regency in designing Project Based Learning Models. The increase was shown (1) the ability of MTs Teachers in Batealit District in Jepara Regency in designing the characteristics of the Project Based Learning Model from $20 \%$ in the first cycle to $100 \%$ in the second cycle; (2) the ability of MTs Teachers in Batealit District in Jepara Regency in identifying Project Based Learning Model constraints from 27\% in the first cycle to $100 \%$ in the second cycle; (3) the ability of MTs Teachers in Batealit District in Jepara Regency in designing the objectives of the Project Based Learning Model, from 27\% in the first cycle to $100 \%$ in the second cycle; (4) the ability of MTs Teachers in Batealit District in Jepara Regency in compiling the steps of the Project Based Learning Model, from 20\% in the first cycle to $100 \%$ in the second cycle; (5) The ability of MTs teachers in Batealit District in Jepara Regency in designing Project Based Learning Models, from 17\% in the first cycle to $100 \%$ in the second cycle. Other information shows that the response of MTs teachers in Batealit Subdistrict in Jepara Regency in participating in the workshop process in order to design a Project Based Learning Model 67\% responded very well and 33\% responded well. 
Vol 1. No 2. November 2021, e-ISSN : 2807-1808 | P-ISSN : 2807-2294

This shows that the MTs teachers in Batealit District in Jepara Regency really expect a workshop to improve their competence.

Keywords: teacher competence, $\mathrm{PjBL}$, workshop process.

\section{PENDAHULUAN}

Perubahan cara pandang terhadap siswa sebagai objek menjadi subjek dalam proses pembelajaran menjadi titik tolak banyak ditemukannya berbagai pendekatan pembelajaran yang inovatif. Mulyasa (2013) Proses pembelajaran yang paling penting adalah apa yang dipelajari peserta didik merupakan kebutuhan dan sesuai perkembangan mereka, bukan yang ingin dicapai oleh guru/ fasilitator. Menurut Uno (2008), hakekat pembelajaran adalah membelajarkan siswa. Sukoco (2019) Pembelajaran itu memfasilitasi peserta didik belajar. Inilah pentingnya model pembelajaran.

Berdasarkan hasil supervisi akademik di MTs Kecamatan Batealit Kabupaten Jepara pada semester genap TP 2016/2017, ditemukan masih minimnya guru menggunakan model pembelajaran Project based learning yaitu hanya 10\%. Responden yang disupervisi akademik berjumlah 30 guru MTs binaan tentang penggunaan model pembelajaran Project based Learning. Berikut disajikan tabel hasil supervisi akademik;

Tabel 1 Hasil supervisi akademik di MTs Kecamatan Batealit

\begin{tabular}{|l|c|c|c|}
\hline NO & JUMLAH RESPONDEN & $\begin{array}{c}\text { MENGGUNAKAN } \\
\text { MODEL PjBL }\end{array}$ & $\begin{array}{c}\text { BELUM MENGGUNAKAN } \\
\text { MODEL PjBL }\end{array}$ \\
\hline 1 & 30 & 3 & 27 \\
\hline & Prosentase & $10 \%$ & $90 \%$ \\
\hline
\end{tabular}

Dari tabel 1 dapat diketahui guru yang menggunakan model pembelajaran model proyect based learning Cuma 3 orang (10\%), sedangkan yang belum ada 27 orang (90\%). Ini sangat memprihatinkan, maka perlu ada perbaikan yaitu melalui kegiatan Workshop Model pembelajaran Project Based Learning (PjBL).

Kondisi ini harus segera diatasi dan ditindaklanjuti dengan mengadakan kegiatan workshop. Salah satu workshop yang akan segera dilaksanakan yaitu workshop merancang Model Project Based Learning.

Pendekatan ini memperkenankan siswa untuk bekerja secara mandiri dalam mengkostruksikannya dalam produk nyata. Dalam Project Based Learning (PjBL), siswa diberikan tugas atau proyek yang kompleks, cukup sulit, lengkap, tetapi realistik dan kemudian diberikan bantuan secukupnya agar mereka dapat menyelesaikan tugas. Di samping itu, penerapan strategi Project Based Learning (PjBL)/ tugas ini mendorong tumbuhnya kompetensi nurturant seperti kreativitas, kemandirian, tanggung jawab, kepercayaan diri, dan berpikir kritis dan analitis.

Dalam Kemdikbud (2017), Project Based Learning (PjBL) (project based learning) adalah model pembelajaran yang menggunakan proyek/kegiatan sebagai tujuannya. Pembelajaran berbasis proyek (PJBL) memfokuskan pada aktivitas siswa yang berupa pengumpulan informasi dan pemanfaatannya untuk menghasilkan sesuatu yang bermanfaat bagi kehidupan siswa itu sendiri ataupun bagi orang lain, namun tetap terkait dengan KD dalam kurikulum.Melalui workshop ini kompetensi guru tentang Model Project Based Learning (PjBL) (project based learning) akan meningkat, sehingga mereka termotivasi untuk mengimplementasikannya dalam pembelajaran.

\section{METODE PENELITIAN}

Metode penelitian ini adalah bentuk penelitian tindakan kepengawasan. Ada empat kegiatan utama yang ada pada setiap siklus pada penelitian tindakan ini, yaitu: perencanaan (planning), pelaksanaan (action), pengamatan (observation) dan refleksi (reflection), demikian dalam (Arikunto (2006), Aqib (2009), Mulyasa, (2009) Suharjono (2012). Hubungan keempat 
komponen tersebut dipandang sebagai suatu siklus. (Widayati, 2008:91) Desain Kurt Lewin dapat dilihat dalam gambar sebagai berikut:

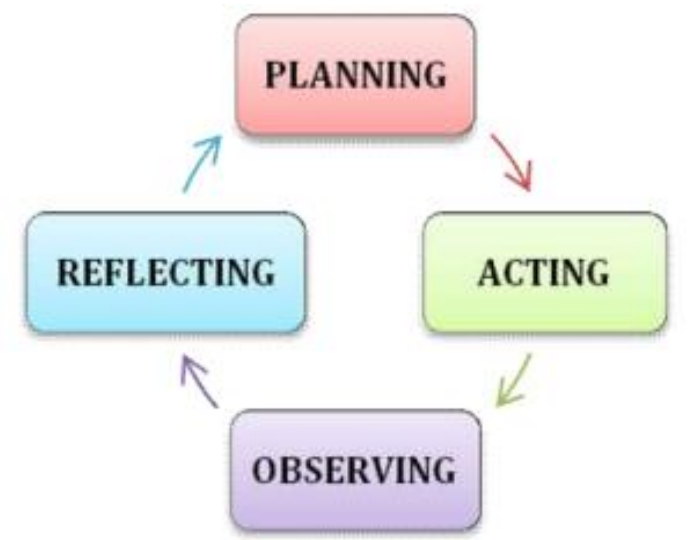

\section{Gambar 1. Model Penelitian Tindakan Kelas}

Kegiatan dalam penelitian tindakan ini dititik-beratkan pada kemampuan guru dalam merancang dan menerapkan suatu modal pembelajaran. Penelitian ini direncakan dilaksanakan dalam beberapa siklus dan masing-masing siklus terdiri atas: perencanaan, pelaksanaan, observasi dan refleksi. Secara rinci prosedur penelitian mengikuti langkah-langkah sebagai berikut; Siklus I, Tahap Perencanaan; kegiatan yang dilakukan sebagai berikut; menyampaikan undangan ke 30 Guru mapel Madrasah Tsanawiyah se Kecamatan Batealit, menyusun jadual workshop: hari Sabtu, 7 Oktober 2017 dan menyiapkan materi workshop. Tahap selanjutnya Pelaksanaan; Hari Sabtu, 7 Oktober 2018: jam 08.00 - 11.30, di MTs Miftahul Huda Ragulampitan Batealit dengan acara; pembukaan, pre tes, pemaparan materi Model Project Based Learning, mengerjakan Lembar Kerja workshop, praktek menyusun RPP berbasis Model Project Based Learning, post tes (Evaluasi). Berikutnya pengamatan; Kesiapan mental dan fisik guru, esiapan bahan-bahan yang dibawa guru pada saat workshop, kehadiran guru. Untuk melaksanakan observasi terhadap pelaksanaan dan hasil pemberian tindakan, menggunakan pedoman observasi sebagai berikut: format Pedoman Observasi Proses Pelaksanaan Workshop, pedoman Observasi Pengetahuan Dasar Peserta, Pedoman Observai Kompetensi Peserta. Tahap terakhir, Refleksi. Refleksi merupakan analisis dari hasil pengamatan berdasarkan data yang diperoleh. Kendala yang pada siklus I, akan dijadikan permasalahan pada siklus II, yang kemudian dilanjutkan dengan merancang tindakan pada siklus berikutnya.

Siklus II, dimulai perencanaan dengan kegiatan yang dilakukan adalah sebagai berikut; menyampaikan undangan kepada 30 Guru mapel Madrasah Tsanawiyah se Kecamatan Batealit, menyusun jadual workshop: hari Sabtu, 14 Oktober 2017, menyiapkan materi workshop dan Review materi Model Porject Based Learning. Pelaksanaan pada hari/ tgl Sabtu, 14 Oktober 2017 di MTs Miftahul Huda Ragulampitan Batealit, dengan acara; pembukaan, refleksi hasil siklus I; memperbaiki RPP berbasis Model Project Based Learning, Post tes (Evaluasi). Tahap berikutnya Pengamatan; kesiapan mental dan fisik guru, bahan-bahan yang dibawa guru pada saat workshop dan guru. Untuk melaksanakan observasi terhadap pelaksanaan dan hasil pemberian tindakan, menggunakan pedoman observasi sebagai berikut: Format Pedoman Observasi Proses Pelaksanaan Workshop, Pedoman Observasi Pengetahuan Dasar Peserta, Pedoman Observai Kompetensi Peserta. Tahap Refleksi. Refleksi merupakan analisis dari hasil pengamatan berdasarkan data yang diperoleh. Data siklus I dan siklus II dibandingkan untuk mengetahui keberhasilan siklus II.

\section{HASIL DAN PEMBAHASAN}

Ada peningkatan kemampuan Guru MTs Kecamatan Batealit di Kabupaten Jepara dalam merancang Model Project Based Learning (PjBL) setelah mengikuti workshop. Dari siklus I ke siklus II dapat mencapai target minimal yang telah ditetapkan dalam merancang 
model pembelajaran pada masing-masing aspek. Dengan demikian dapat disimpulkan bahwa melalui workshop dapat meningkatkan kompetensi guru dalam merancang Model Project Based Learning (PjBL).

\section{Hasil}

\section{Deskripsi Siklus I}

a. Perencanaan

Dalam Perencanaan meliputi (1) mengumpulkan guru melalui undangan kepala madrasah; (2) menyusun jadual workshop: hari, tanggal, jam dan tempat; (3) menyiapkan materi workshop; pengarahan kepala madrasah, pemaparan materi Model Project Based Learning (PjBL); (4) menyiapkan konsumsi untuk workshop; dan (7) menyuruh guru membawa laptop.

\section{b. Pelaksanaan}

Pada tahap ini dilakukan beberapa langkah, yakni: (1) absensi peserta; (2) pengarahan kepala madrasah; (3) penjelasan umum kepada seluruh peserta; (4) peserta diajak mereview Model Project Based Learning (PjBL); (4) guru mengkaji langah-langkah menyusun Model Project Based Learning (PjBL); (5) guru melakukan persiapan Model Project Based Learning $(P j B L)$; dan (6) presentasi visual dalam menyusun Model Project Based Learning (PjBL).

\section{c. Pengamatan}

Pada tahap ini dilakukan pengamatan terhadap pelaksanaan tindakan, yaitu menitikberatkan pada kompetensi guru dalam menyusun Model Project Based Learning $(P j B L)$ sebagai akibat diterapkannya workshop. Tujuan dilaksanakan pengamatan adalah untuk mengetahui kegiatan yang mana patut dipertahankan, diperbaiki, atau dihilangkan sehingga kegitan pembinaan melalui workshop benar-benar berjalan sesuai dengan tujuan yang ada dan mampu meningkatkan kinerja peserta dalam menyusun Model Project Based Learning (PjBL).

Kegiatan peserta juga diobservasi, baik menyangkut kesiapan mental dan fisik guru, kesiapan bahan-bahan yang dibawa guru pada waktu workshop, kesiapan laptop, pengetahuan dasar tentang Model Project Based Learning (PjBL), dan kemampuan menyusun Model Project Based Learning (PjBL).

\section{d. Refleksi}

Dari hasil yang diperoleh menunjukkan bahwa guru dalam merancang Model Project Based Learning (PjBL) pada siklus I belum menunjukkan hasil yang sesuai dengan indikator yang telah ditetapkan. Setelah diadakan refleksi terhadap hasil yang diperoleh, diputuskan untuk memperbaiki dari segi kegiatan workshop terutama memperjelas tentang aspek-aspek yang belum sesuai dengan indikator yang telah ditetapkan. Dari hasil tersebut tampaknya secara umum bahwa guru dalam merancang Model Project Based Learning (PjBL) belum memenuhi kriteria yang telah ditetapkan.

Terkait dengan kesiapan guru, ditemukan bahwa guru belum menyadari bahwa pentingnya kemampuan merancang Model Project Based Learning (PjBL). Terkait dengan kesiapan laptop, guru masih banyak yang belum memiliki; alternatif solusinya adalah meminjam pada madrasah lain atau memanfaatkan komputer yang ada di madrasah. Berdasarkan hasil refleksi itu, diputuskan untuk memantapkan kegiatan pembinaan lebih memfokuskan pada aspek-aspek yang belum memenuhi indikator yang telah ditetapkan.

Dari masalah tersebut, diputuskan untuk memperbaiki beberapa langkah dalam siklus I, yakni memfokuskan pada penjelasan tentang format dan aspek penilaian dalam kaitannya dengan mrancang Model Project Based Learning (PjBL). Langkah-langkah ini dijalankan pada siklus II dengan tetap mempertahankan kegiatan yang lain yang sudah dianggap baik. Untuk meningkatkan kesiapan guru, fasilitator memberikan kesadaran bahwa betapa penting 
Vol 1. No 2. November 2021, e-ISSN : 2807-1808 | P-ISSN : 2807-2294

kemampuan merancang Model Project Based Learning (PjBL) bagi guru sebagai kompetensi yang harus dimiliki oleh guru.

\section{Deskripsi Siklus II}

\section{a. Perencanaan}

Perencanaan teknis pelaksanaan kegiatan seperti: (1) mengumpulkan guru melalui undangan kepala madrasah; (2) menyusun jadual workshop: hari, tanggal, jam dan tempat; (3) menyiapkan materi workshop; pengarahan kepala madrasah, pemaparan materi strategi/model pembelajaran; (4) menyiapkan konsumsi untuk workshop; dan (5) menyuruh guru membawa laptop.

\section{b. Pelaksanaan}

Pada tahap ini dilakukan beberapa langkah, yakni: (1) absensi peserta; (2) pengarahan kepala madrasah; (3) penjelasan umum kepada seluruh peserta; (4) peserta diajak mereview Model Project Based Learning (PjBL); (5) guru mengkaji langah-langkah menyusun Model Project Based Learning (PjBL); (6) guru melakukan persiapan Model Project Based Learning $(P j B L)$; dan (7) presentasi visual dalam menyusun Model Project Based Learning (PjBL).

\section{c. Pengamatan}

Pada tahap ini dilakukan pengamatan terhadap pelaksanaan tindakan, yaitu menitikberatkan pada kompetensi guru dalam menyusun Model Project Based Learning $(P j B L)$ sebagai akibat diterapkannya workshop. Tujuan dilaksanakan pengamatan adalah untuk mengetahui kegiatan yang mana patut dipertahankan, diperbaiki, atau dihilangkan sehingga kegitan pembinaan melalui workshop benar-benar berjalan sesuai dengan tujuan yang ada dan mampu meningkatkan kinerja peserta dalam menyusun Model Project Based Learning (PjBL).

Pada siklus II ini, langkah-langkah yang diambil sesuai dengan refleksi hasil siklus I, mengikuti langlah-langkah seperti siklus I dengan memfokuskan pada penjelasan aspek-aspek yang belum dipahami guru dalam menyusun Model Project Based Learning (PjBL) lebih menitikberatkan pada aspek pembimbingan secara individu. Dari 30 orang guru semua dilibatkan dalam siklus II untuk memperdalam pengetahuan tentang penyusunan Model Project Based Learning (PjBL).

\section{d. Refleksi}

Dari hasil yang diperoleh menunjukkan bahwa guru dalam merancang Model Project Based Learning (PjBL) pada siklus II sudah menunjukkan hasil yang sesuai dengan indikator yang telah ditetapkan. Setelah diadakan refleksi terhadap hasil yang diperoleh, diputuskan untuk tidak melanjutkan pada siklus berikutnya Dari hasil tersebut tampaknya secara umum bahwa guru dalam merancang Model Project Based Learning (PjBL) sudah memenuhi kriteria yang telah ditetapkan.

Terkait dengan kesiapan guru, ditemukan bahwa guru sudah menyadari betapa pentingnya kemampuan merancang Model Project Based Learning (PjBL). Terkait dengan kesiapan laptop, semua guru sudah membawa laptop.

\section{Perbandingan Siklus I dan Siklus II \\ a. Perbandingan Kesiapan Mengikuti Workshop}

Tabel 2. Perbandingan Kesiapan Guru Mengikuti Workshop

\begin{tabular}{|c|l|c|c|c|}
\hline \multicolumn{5}{|c|}{ KESIAPAN GURU MENGIKUTI WORKSHOP } \\
\hline No. & \multicolumn{1}{|c|}{ Aspek yang diamati } & Siklus I & Siklus II & Keterangan \\
\hline 1. & Kesiapan fisik dan mental & $27 \%$ & $100 \%$ & Meningkat \\
\hline 2. & Kesiapan bahan & $20 \%$ & $100 \%$ & Meningkat \\
\hline 3. & Kesiapan laptop & $20 \%$ & $100 \%$ & Meningkat \\
\hline
\end{tabular}


Tabel 2 menggambarkan ada peningkatan kesiapan guru mengikuti workshop dari siklus I ke Siklus II, kesiapan fisik dan mental naik 73\%, kesiapan bahan naik 80\%, kesiapan laptop naik $80 \%$. Ini menunjukkan kegiatan workshop memberi manfaat dan pengaruh yang baik terhadap kesiapan guru, bahwa suatu kegiatan itu harus dispkan dengan sebaik-baiknya.

\section{b. Perbandingan Pengetahuan Tentang Project Based Learning (PjBL)}

Tabel 3. Perbandingan Pengetahuan Guru Tentang Model PjBL

\begin{tabular}{|c|l|c|c|c|}
\hline \multirow{2}{*}{ No. } & \multicolumn{1}{|c|}{ Aspek yang diamati } & Siklus & Siklus & Keterangan \\
\cline { 2 - 4 } & Pengetahuan tentang: & $20 \%$ & $100 \%$ & Meningkat \\
\hline 1. & Project Based Learning (PjBL) & $20 \%$ & $100 \%$ & Meningkat \\
\hline 2. & Karakteristik PJBL & $20 \%$ & $100 \%$ & Meningkat \\
\hline 3. & Kesulitan dalam PJBL & $27 \%$ & $100 \%$ & Meningkat \\
\hline 4. & Tujuan PJBL & $27 \%$ & $100 \%$ & Meningkat \\
\hline 5. & Langkah-langkah dalam PJBL & $20 \%$ & $100 \%$ & Meningkat \\
\hline 6. & Kegiatan siswa dalam PJBL & $20 \%$ & $100 \%$ & Meningkat \\
\hline 7. & Penyelesaian proyek dalam PJBL & $20 \%$ & $100 \%$ & Meningkat \\
\hline 8. & Penyampaian hasil dalam PJBL & & & \\
\hline
\end{tabular}

Tabel 3 menggambarkan ada peningkatan pengetahuan guru tentang Model Project Based Learning dari siklus I dan siklus II. Rata-rata peningkatannya 78\%. Jadi workshop sangat efektif meningkatkan pengetahuan guru memahami model Model Project Based Learning.

\section{c. Perbandingan Kompetensi Guru dalam Merancang Project Based Learning (PjBL)}

Tabel 4. Perbandingan Kompetensi Guru Merancang Model PjBL

\begin{tabular}{|c|l|c|c|c|}
\hline \multicolumn{4}{|c|}{ PERBANDINGAN KEMAMPUAN MERANCANG PJBL } \\
\hline \multirow{2}{*}{ No. } & \multicolumn{1}{|c|}{ Aspek yang dinilai } & Siklus & Siklus & I \\
\cline { 2 - 5 } & Kemampuan dalam: & II & \\
\hline 1. & Menentukan proyek & $20 \%$ & $100 \%$ & Meningkat \\
\hline 2. & Merancang proyek & $27 \%$ & $100 \%$ & Meningkat \\
\hline 3. & Menyusun jadwal kegiatan & $27 \%$ & $100 \%$ & Meningkat \\
\hline \multirow{2}{*}{4.} & $\begin{array}{l}\text { Menyelesaikan dan } \\
\text { menyampaikan hasil }\end{array}$ & $20 \%$ & $100 \%$ & Meningkat \\
\hline 5. & Mengevaluasi proses dan hasil & $17 \%$ & $100 \%$ & Meningkat \\
\hline
\end{tabular}

Tabel 4 menjelaskan peningkatan kompetensi guru dalam merancang Model Project Based Learning (PjBL) dari siklus I dan siklus II. Rata-rata peningkatannya $77 \%$, ini menunjukkan bahwa dengan workshop sangat efektif meningkatkan kompetensi guru dalam merancang Model Project Based Learning (PjBL).

\section{Pembahasan}

Berdasarkan analisis dan pembahasan seperti yang telah dipaparkan pada bagian sebelumnya, maka dapat disimpulkan bahwa terjadi peningkatan aktivitas peserta dalam kegiatan workshop tentang penyusunan Model Project Based Learning (PjBL) bagi guru. Di samping itu juga, terjadi peningkatan kinerja guru dalam menyusun Model Project Based Learning (PjBL) melalui workshop. Dari siklus I ke siklus II pada masing-masing aspek dengan target ketercapaian sesuai dengan kriteria yang ditetapkan. Dengan demikian dapat disimpulkan 
Vol 1. No 2. November 2021, e-ISSN : 2807-1808 | P-ISSN : 2807-2294

bahwa melalui workshop dapat meningkatkan kinerja guru dalam menyusun Model Project Based Learning (PjBL).

Keberhasilan tindakan ini disebabkan oleh pemahaman secara menyeluruh tentang strategi pembelajaran sangat diperlukan. Dengan pemahaman yang baik, maka model pembelajaran dapat disusun dengan baik. Mengoptimalkan pemahaman guru terhadap Model Project Based Learning (PjBL) melalui pembinaan intensif dalam bentuk penyelenggaraan workshop menunjuk pada metode kooperatif konsultatif dimana diharapkan para guru berdiskusi, bekerja sama dan berkonsultasi secara aktif. Aktivitas ini akan sangat membantu mereka dalam memahami konsep-konsep dasar penyusunan model pembelajaran yang pada akhirnya nanti mereka mampu menyusun model pembelajaran yang lain dengan baik dan benar.

Dalam kaitannya dengan pembinaan melalui workshop, maka penelitian ini juga sesuai dengan apa yang dikatakan Sinaga dan Sitorus (2019) bahwa Tujuan workshop untuk mendorong siswa mempergunakan fasilitas teknologi komputer yang tidak berbayar guna menambah skil dan berbagi ilmu pengetahuan. Workshop dimaksudkan untuk mempertinggi kinerja dengan mengembangkan cara-cara berpikir dan bertindak yang tepat serta pengetahuan tentang tugas pekerjaan termasuk tugas dalam melaksanakan evaluasi diri.

Dari paparan di atas, menunjukkan bahwa peningkatan kompetensi guru melalui kegiatan workshop yang lebih menekankan pada metode kolaboratif konsultatif akan memberikan kesempatan sharing antara satu guru dengan guru lain. Dengan demikian, pemahaman terhadap model Model Project Based Learning (PjBL) dapat ditingkatkan baik dalam teoretisnya maupun implementasinya.

\section{KESIMPULAN}

Penelitian ini dapat disimpulkan;

a. Ada peningkatan kemampuan Guru MTs Kecamatan Batealit di Kabupaten Jepara dalam merancang Model Project Based Learning $(P j B L)$ setelah mengikuti workshop. Dari siklus I ke siklus II ada peningkatan yang signifikan yaitu mencapai kenaikan $77 \%$ dalam merancang model pembelajaran pada masing-masing aspek. Dengan demikian dapat disimpulkan bahwa melalui workshop dapat meningkatkan kompetensi guru dalam merancang Model Project Based Learning (PjBL).

b. Guru MTs Kecamatan Batealit di Kabupaten Jepara memberikan respon sangat positif terhadap kegiatan merancang Model Project Based Learning (PjBL) melalui workshop yakni peningkatan $77 \%$. Dengan demikian kegiatan workshop memberikan dampak positif terhadap kinerja guru dalam merancang Model Project Based Learning (PjBL).

\section{DAFTAR PUSTAKA}

Aqib, Zainal. (2009). Penelitian Tindakan Kelas, Bandung: Yrama Widya.

Arikunto, Suharsimi. (2006). Prosedur Penelitian Suatu Pendekatan Praktik, Jakarta: Rineka Cipta.

Kementerian Pendidikan dan Kebudayaan. (2017). Model-Model Pembelajaran, Jakarta.

Mulyasa E. (2013). Pengembangan dan Implementasi Kurikulum, Bandung: PT Remaja Rosda Karya

Sitorus, Martua \& Sinaga, RM, Sindar, Anita, Selaparang Jurnal Pengabdian Masyarakat Berkemajuan, Penerapan Teknik Workshop Pada Pembuatan Blog Bagi Pemula Di SMA Al Washliyah 12 Perbaungan, from https://scholar.google.com/citations, 27/7/21, 9:21 AM.

Sukoco, Heru. (2019). Implementasi Proses dan Hasil Pembelajaran Kurkulum 2013 untuk SMP/MTs, Yogyakarta: CV. Danadyaksa.

Supardi, Suharjono. (2012). Strategi Menyusun Penelitian Tindakan Kelas, Yogyakarta: Andi Offset.

Uno, Hamzah B. (2008). Perencanaan Pembelajaran, Jakarta: PT Bumi Aksara. 
Widayati, Ani. (2008). Penelitian Tindakan Kelas. Jurnal Pendidikan Akuntansi Indonesia, Vol. VI No. 1. 